\title{
SURVEY OF MITES ASSOCIATED WITH STORED ONION BULBS AT EL-MENOFIA GOVERNORATE
}

\author{
YASSIN, E. M. A., A.M. KHALIL and S. A. A. OSMAN
}

Plant Protection Research Institute, ARC, Dokki, Giza, Egypt

(Manuscript received 1 August 2016)

\begin{abstract}
A survey on mites associated with stored onion bulbs at ElMenofia governorate during 2014 and 2015 years, proved the occurrence of 21 different species. Of these, eight species from two families Acaridae and Glycyphagidae belong to Astigmata, six species belong to five families (Bdellidae, Rhagididae, Cheyletidae, Tydeidae and Neophyllobidae) under Prostigmata, 6 species in 3 families (Ascidae, Laelapidae and Ameroseiidae) belong to Mesostigmata and one mite species in one family (Oppiidae) under Suborder Cryptostigmata. Members of the families Acaridae, Glycyphagidae and Cheyletidae were the most common mites, found in many samples with high abundance. The storage conditions affected on the abundance of different collected mites, as Rhizoglyphus echinopus, Tyrophagus putrescentiae, Caloglyphus berlesei (Family Acaridae), Glycyphagus ornatus (Family Glycyphagidae); and Cheyletus eruditus, Family (Cheyletidae); were recorded from the different three storage conditions. On the other hand, Lardoglyphus konoi, Lardoglyphus zacheri, Tyrophagus tropicus, Spinibdella bifurcata, Coccorhagidia clavifron, Lasioseius eagypticus, Lasiosius lindiquisti, Androlaelaps wahabi, Kleemenia plumosus and K. zaheri were collected from the bulbs which exposed to straw covered bulbs condition. On the other hand, Pronematus rykei (Tydeidae) and Neophyllobius aegyptium (Neophyllobidae) were identified species when onion bulbs stored with opened and shady room condition; while Cheyletus badryi (Cheyletidae) was isolated from onion bulbs stored at straw covered bulbs and Indoor storage conditions.
\end{abstract}

\section{INTRODUCTION}

The loss of foods in the post-harvest system is not new; it has always been a problem for mankind. In these days of rapidly enlarging population in the poorest countries of the world where food is already short, there is an increasing urgency to do a better job of conserving mankind food supply in order to alleviate hunger and malnutrition. Onion, Allium cepa L., is one of the most important vegetable crops in Egypt in terms of crop value, Mostafa (2011). The fresh onions are spring and summer crops, high in water and sugar content and noted for their sweet, mild flavor, Chomchalow (2003). Storage mites are important pests of all types of stored commodities. They are not only responsible for direct damage in form of weight reduction but also imply the indirect damage in form of germination loss of the grains, 
deterioration of the nutrients and quality of the stored grains and other stored products. Some granary mites transmit disease agents to agricultural crops, e.g. Botrytis allii Munn to onion (E1-Atrozy, 1974). Diaz et al., (1999) mentioned that bulb mites of the genus Rhizoglyphus (Claparede) (Acari: Acaridae) have been identified as pests of many crops and ornamentals in storage, in the greenhouse, and in the field and the most important hosts are species in the family Liliaceae (e.g. Allium spp.).The authors added that also, mite populations grew faster on Fusarium-infested bulbs, suggesting that infestation by this pathogen creates conditions favorable to mite development. Survey conducted by Mostafa (2011) in Egypt indicated the presence of 12 mite species associated with stored onion bulbs, Allium cepa L. Rangarajan et al., (1971) in India found unidentified species of Rhyzoglyphus infesting stored onion bulbs. Group of 5-10 mites were found under the outer sheath, while sever infestation was found inside the bulbs. So, the current study is conducted to study the effect of different storage conditions on the abundance of stored mites on onion bulbs at ElMenofia governorate.

\section{MATERIALS AND METHODS}

Samples of about 10 onion bulbs (randomized collected) were taken from four different locations (Ashmoun, El-Sadat and Quiesna regions), Menofia governorate at all storage conditions (straw covered bulbs, opened and shady room and indoor) for each mentioned districts). The study conducted in two seasons 2014 and 2015. Samples were collected in polyethylene bags, then transferred to laboratory for inspection in the same collection day. Isolated mites were identified and recorded. Mites are isolated by using modified Tullgern's funnel kept for about 24 hours below 60-watt electric lamp. Collected mites were put in Nesbitt's clearing agent, then mounted on glass slide using Hoyer's medium for examination. Labels with necessary data were stuck on the slides. Identification of species followed on review given by Hughes (1961), Attiah (1969), Zaher (1986) and Krantz and Walter (2009).

\section{RESULTS AND DISCUSSION}

A general survey at three different regions of El-Menofia governorate mentioned before was undertaken for two years 2014 and 2015. The study revealed the occurrence of 21 different mite species belonging to 14 genera and 10 families under four suborders as follows, Table (1). 
Table 1. Occurrence of mite species associated with stored onion under different storage methods.

\begin{tabular}{|c|c|c|c|c|c|}
\hline Mite families & Mite species & Storage condition & Feeding nature & Locality & Abund. \\
\hline \multicolumn{6}{|c|}{ Suborder Acaridida } \\
\hline \multirow[t]{7}{*}{ Acaridae Leach } & Rhizoglyphus echinopus (F. \& R.) & $A, B$ and $C$ & Fungivorous & All regions & +++ \\
\hline & Lardoglyphus konoi (Sasa and Asanuma) & A & Fungivorous & Ashmoun & + \\
\hline & Lardoglyphus zacheri Oudemans & A & Fungivorous & Ashmoun & + \\
\hline & Tyrophagus tropicus Robertson & A & Fungivorous & Ashmoun & + \\
\hline & Tyrophagus putrescentiae (Schrak) & $A, B$ and $C$ & Fungivorous & All regions & +++ \\
\hline & Caloglyphus berlesei (Michael) & $A, B$ and $C$ & Fungivorous & All regions & +++ \\
\hline & Caloglyphus beta Atiah & $A$ and $B$ & Fungivorous & Ashmoun & ++ \\
\hline Glycyphagidae Berlese & Glycyphagus ornatus (Kramer) & $A, B$ and $C$ & Fungivorous & Ashmoun & +++ \\
\hline \multicolumn{6}{|c|}{ Suborder Actinedida } \\
\hline Bdellidae Duges & Spinibdella bifurcata_Atyeo & A & Predator & Ashmoun & + \\
\hline Rhagidiidae Oudemans & Coccorhagidia clavifron Canestrini & A & Predator & Ashmoun & + \\
\hline
\end{tabular}


Table (1): Cont

Mite families

Mite species

\section{Storage \\ condition}

Suborder Actinedida

\begin{tabular}{|c|l|l|l|l|}
\hline $\begin{array}{c}\text { Cheyletidae } \\
\text { Leach }\end{array}$ & Cheyletus eruditus (Shrank) & A, B and C & Predator & All regions \\
\cline { 2 - 5 } & Cheyletus badryi Zaher and Hassan & A and C. & Predator & Quiesna \\
\hline Tydeidae Kramer & Pronematus rykei (Baker) & B & Predator & Quiesna \\
\hline Neophyllobidae & Neophyllobius aegyptium Soliman and Zaher & B & Predator & Quiesna \\
\hline
\end{tabular}

Suborder Gamasida

\begin{tabular}{l}
$\begin{array}{c}\text { Ascidae Voigts and } \\
\text { Oudemans }\end{array}$ \\
$\begin{array}{l}\text { Laelapidae } \\
\text { Berlese }\end{array}$ \\
\hline
\end{tabular}

Ameroseiidae

Evans

\begin{tabular}{|l|}
\hline Lasioseius eagypticus Afifi \\
\hline Lasiosius lindiquisti Nasr and Abou -Awad \\
\hline Androlaelaps wahabi Metwaly and Ibraheem \\
\hline Androlaelaps casalies (Berlese ) \\
\hline Kleemenia plumosus Oud. \\
\hline Kleemenia zaheri El-Badry, Nasr and Hafez \\
\hline
\end{tabular}

\begin{tabular}{|l|c|}
\hline A & Predator \\
\hline A & Predator \\
\hline A & Predator \\
\hline A and B & Predator \\
\hline A & Predator \\
\hline A & Fungivorous \\
\hline
\end{tabular}

Ashmoun

Ashmoun

Ashmoun

\begin{tabular}{l|l} 
Ashmoun and Quiesna & + \\
\hline
\end{tabular}

Ashmoun

Ashmoun

$+++$

Suborder Oribatida

\begin{tabular}{|l}
\hline Oppiidae Grandjean \\
A = straw covered bulbs
\end{tabular} Oppiia sticta Popp B

Fungivorous

Quiesna

$+++$

$+=$ rare $(1-3$ individuals $)$

B- opened shady room

$\mathrm{C}=$ Indoor

$++=$ moderate (4-8 individuals)

+++ high (more than 8 individuals) 


\section{1- Sub-order: Acaridida}

This sub-order was represented by eight mite species belonging to five genera under two families Acaridae and Glycyphagidae. The species were Rhizoglyphus echinopus, Lardoglyphus konoi, L. zacheri, Tyrophagus tropicus, T. putrescentiae, Caloglyphus berlesei and C.beta (Acaridae) and Glycyphagus ornatus (Glycyphagidae).

The feeding habit of these mite species in this suborder is regarded as fungivorous according to Zaher (1986) and Mostafa et al., (2006).

\section{2- Suborder: Actinedida}

Six species belonging to five genera belong to five families represented suborder Actinedida were collected. All of the collected actinedid mites are pedators on other associated stored onion pets. These species and families were Spinibdella bifurcata Atyeo (Bdellidae); Coccorhagidia clavifron Canestrini (Rhagididae); Cheyletus eruditus (Shrank) and Cheyletus badryi Zaher and Hassan (Cheyletidae); Pronematus rykei (Baker) (Tydeidae); Neophyllobius aegyptium Soliman and Zaher (Neophyllobidae).

All collected actinedid mites were fed as predacous mites, Table (1), Zaher (1986).

\section{3- Suborder: Gamasida}

The current study indicated that the onion bulbs in Menofia Governorate infested wit six different mesostigmatid mites belonging to three different families, two species for each family. The mites were Lasioseius eagypticus and L. lindiquisti (family: Ascidae); Androlaelaps wahabi and A.casalies (family: Laelapidae) and Kleemenia plumosus and K. zaheri (family: Ameroseiidae). The first four mites are regard as predacous mites, but the last two once (Ameroseiid mites) were observed fed as fungivorous mites, Zaher (1986).

\section{4- Suborder: Oribatida:}

The only collected oribatid mite in this study was Oppiia sticta with high abundance which feeds as fungivorous mite, Zaher (1986).

As shown in Table (1), the storage conditions affected on the abundance of different collected mites, as $R$. echinopus, Tyrophagus putrescentiae, $C$. berlesei (Family Acaridae), G. ornatus (Family Glycyphagidae); and C. eruditus, Family (Cheyletidae); where surveyed from the different three storage conditions, straw covered bulbs, opened and shady room and Indoor conditions. On the other hand, Lardoglyphus konoi, Lardoglyphus zacheri, Tyrophagus tropicus, Spinibdella bifurcata, Coccorhagidia clavifron, Lasioseius eagypticus , L. lindiquisti , Androlaelaps wahabi , Kleemenia plumosus and $K$. zaheri wee collected from the bulbs which exposed to straw covered bulbs condition. On the other hand, Pronematus rykei (Tydeidae) and N. aegyptium (Neophyllobidae) were the identified species when onion bulbs stored 
with opened and shady room condition; while C. badryi (Cheyletidae) was extracted from onion bulbs stored at straw covered bulbs and Indoor storage conditions, Table (1).

The identified species varied in their abundance from one district to another (Table 1). These findings are in accordance with the fact that the bulb mite, $R$. echinopus is generally the most important and most frequent stored product mite on stored onion bulbs (Sandhu 1976; Smirnov and Smirnova 1978; Lee and Wen 1980; Gerson et al., 1985 and Gerson et al., 1991). Mostafa (2011) noticed that the predatory mite Macrocheles africanus was dominant and accessory, it was found in decaying onion bulbs that heavy infested with onion bulb fly larvae Eumerus amoenus Loew and acarid mites Baker and Wharton (1952) observed that in the field, the mite $R$. echinopus apparently di little damage to healthy onion plants affected only rotted bulbs, but if the mites became established in stored bulbs they appeared to hasten decay. Although it usually fed on rotted or decayed tissues, the mite could infest healthy tissues if in contact with it. Mostafa et al., (2006) collected ninety-three species of mites belonging to 53 genera and 26 families and four suborders in association with stored products at 16 governorates in Egypt. Only two species Pyemotes herfesi (Oudemans) (Pyemotidae) Lasioseius bispinosus Evans (Ascidae) were collected associated with onion bulbs at Sohag and El-Menofia Governorates, respectively. Rhizoglyphus echinopus (F.\& R.) as cosmopolitan species, occurring on bulbs of bulbous plants, in soil, compost and retting plants was found on potato, tulip, hyacinth, lily and onion bulbs. Sollerz et al., (2004). The current survey emphasizes the important of mites on stored onion bulbs, information that may aid in understanding and preventing losses caused by mite contamination of these stored agricultural products

\section{REFERENCES}

1. Attiah, H. H. 1969.Tyroglyphid mies associated with stored food in U.A.R. Egypt. Min. Agric., Plant Prortect.Dep.Tech. Bull.,10:1-51.

2. Baker, E.W. and G.W. Wharton 1952. An introduction to Acarology. Macmillan Co. New York City, 1- 465.

3. Chomchalow, N. 2003. Protection of stored products with special reference to Thailand. AU J.T. 7 (1): 31-47.

4. Diaz, A.; K. Okabe; C.J. Eckenrode; M. G. Villania and B.M. O'Connor. 1999. Biology, ecology, and management of the bulb mites of the genus Rhizoglyphus (Acari: Acaridae). Exp. \& App. Acarol. 24: 85-113. 
5. E1-Atrozy, N. A. 1974. Studies on acarids associated with onion bulbs and ornamental corms. Ph.D. Thesis, Fac0 of Agric., Cairo Univ.,134 pp.

6. Gerson, U; E. Cohen and S. Capua 1991. Bulb mite, Rhizoglyphus robini (Astigmata : Acaridae) as an experimental animal. Exp. Appl. Acarol.,12: 1-2 : 103-110.

7. Gerson, U.; S. Yathom; S. Capua and D. Thorens 1985. Rhizoglyphus robini Claparède (Acari: Astigmata: Acaridae) as a soil mite Acarologia, 26 (4): 371-380.

8. Hughes, A. M. 1961. The mites of stored food. Min. Agic. Fishers and Food Tech Bull. 9: London: $287 \mathrm{pp}$.

9. Krantz, G.W. and D.E. Walter 2009. A manual of Acarology, $3^{\text {rd }}$ ed. , Texas Tech Univ., Press.

10. Lee, H. S. and H.C. Wen 1980. Field investigation of the acarid bulb mites on onion and their control. J. Agric.Res. China, 29-3: 211-218.

11. Mostafa, E. M. 2011. Incidence of mites inhabiting stored onion bulbs in Egypt, with description of a new species of the genus Lasioseius Berlese (Acari : Gamasida). Plant Prot. and Path., Mansoura Univ., Vol. 2 (10): 855 -863, 2011

12. Mostafa, A.M.; Fatma, E. Mohamed, E.M.A. Yassin, and Azza, A. Mohamed 2006. Occurrence of mite species associated with stored products in Egypt. Egypt. J.Appl. Sci., 21 (12 A): 227-

13. Rangarajan, A.V.; N. R. Mahadevan and C. Amalraj 1971. Occurrence of the bulb mite, Rhyzoglyphus. on onion in storage. Indian J. Entomol., 33; 355-356.

14. Sandhu, G. S. 1976. New record of bulb mite Rhizoglyphus echinopus (Fumouze and Robin) from stored onions in India. Sci. Culture, 42(4):221-222.

15. Smirnov, K. S. and G. M. Smirnova 1978. Pests and diseases of onion. Zashchita Rastenii, pp.53

16. Solarz, K., P. Szilman; E. Solarz, M. Krazak and A. Jagla 2004. Some allergenic species of astigmatid mites (Acari, Acaridida) from different synanthropic environments in Southern Poland. Acta Zoologica Cracoviensia, 47(3-4): 125-145.

17. Zaher, M. A. 1986. Incidence of mites associated with stored seeds and food products in Upper Egypt. Exp. \& App. Acarol, 2: 19-24. 


\section{حصر الاكاروسات المرتبطة بكورمات البصل المخزنة فى محافظة المنوفية}

عصام محمد عبد السلام ياسين - عابدين محمود خليل - صدقى عبدالحميد عبد الراضي عثمان

$$
\text { معهد بحوث وقاية النباتات- مركز البحوث الزراعبة - الدقى - جيزة - مصر }
$$

تصاب كورمات البصل المخزنة بالعديد من اكاروسات المواد المخزونة اثثاء فترة التخزين

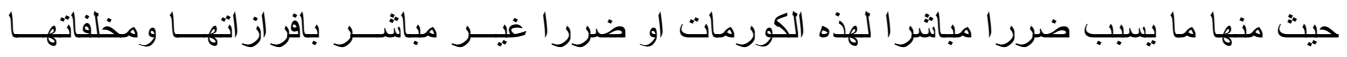
المختلفة كما توجد بعض الاكاروسات التى تمارس تغذيتها بالافتز اس على هذه الاكاروسات وغير هاتيات

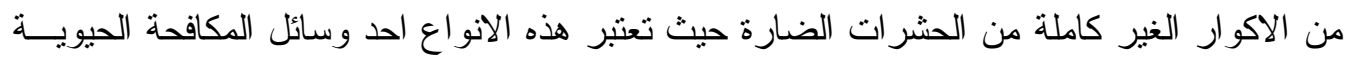

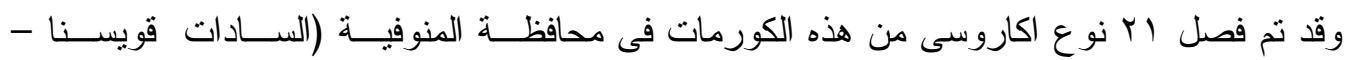

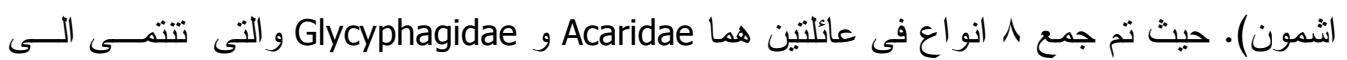

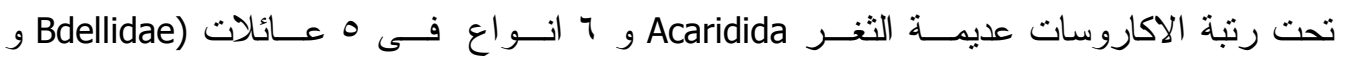

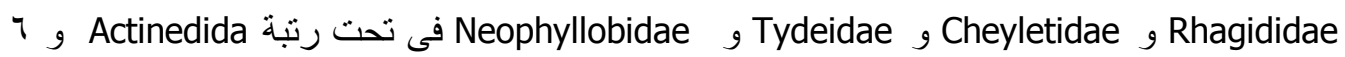

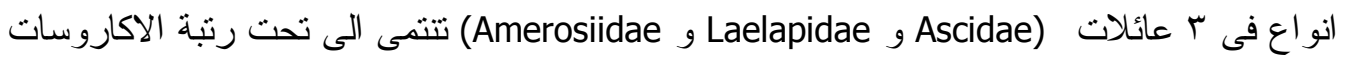
ذات الثغر المتوسط Gamasida ونوع و احد فقط يتبع عائلة Oppiidae و الذى ينتمى الى اكاروســات

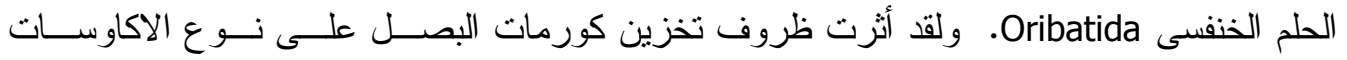

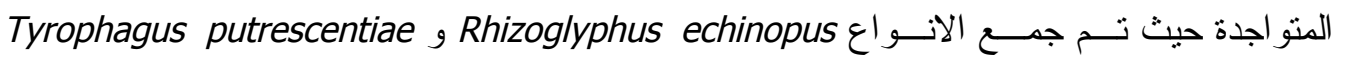
و Cheyletus eruditus و Glycyphagus ornatus Caloglyphus berlesei تحت جميع الظروف التى تعرضت لها الابصال وهى (المغطاه بالقش و الموجودة فى الحجرات المظللة المفتوحة و المخزنة

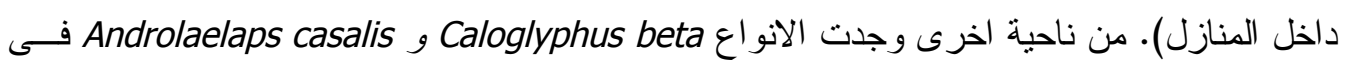
كلا من الابصـال التى خزنت تحت القش وداخل الحجرات المظللة المفتوحسـة و النــوع ع Cheyletus badryi 